\title{
Drivers of Audit Failures: A Comparative Discourse
}

\author{
Etim, E. Osim \\ (Corresponding Author) \\ Department of Accounting \\ Faculty of Business Administration \\ University of Uyo, Nigeria
}

\author{
Comfort Precious Goddymkpa \\ Department of Business \\ Administration \\ Faculty of Education \\ University of Uyo, Nigeria
}

\author{
Nsima Johnson Umoffong \\ Department of Accounting \\ Faculty of Business Administration \\ University of Uyo, Nigeria
}

\begin{abstract}
The aim of this study is to identify the most potent factors driving audit failures by theoreticallyexploring two most publicized corporate and external audit failures cases in Nigeria and globally (EnronAndersen and Cadbury Akintola Williams Deloitte). An exploratory case study approach was adopted to analyze the selected two cases and several other external audit failures in extent literature. Findings reveal that audit failure factors are the same in the cases analyzed and compared and include poor audit approach, negligence and incompetency from the auditors, lack of professional questioning attitude, connivance with clients, fee dependence on major clients, long tenured appointment, external auditors acting as internal auditors to client and rendition of Management Advisory Services (MAS), blatant disregard to accounting standards on auditing, among others. Based on these findings, the following recommendations were made: more stringent sanctions be molted to defaulters, regular review and update of accounting and auditing standards to take care contemporary developments, prohibition of external auditors from rendering multiple MAS, adherence to ethical principles, strengthening of corporate governance structure as well as improved oversight functions by regulatory authorities on the activities of corporate management and auditors.
\end{abstract}

Keywords:- Audit failures, account manipulations, negligence, lack of competency, MAS.

\section{INTRODUCTION}

The practice of auditing globally enhances economic growth and development as well as channeling of funds from sectors with low economic returns to those of higher returns. Auditors serve as assessors and watchdogs of corporate entities on those entrusted with the management of organizational resources. The opinion expressed by them on financial statements of reporting entities is equated to giving assurance to the users of the reports that all is at least fairly well, and that the users can rely on the contents for investments and other allied decisions. The gatekeepers' role in the protection of investors and the economy makes accounting and auditing a "public interest-oriented profession. Serving as gate-keepers or watchdogs, auditors are supposed to bark or raise an alarm should they detect or find out something went wrong along the financial reporting value-chain or process.
Importantly, auditors play prominent role in ensuring accountability and transparency in handling corporate governance issues as they are theorize to prevent corporate reporting maneuver and financial impropriety (Etim and Udoh, [1]). The auditors' role stem from the fact the primary responsibility of reporting company's economic activities rest on the directors and management of the entities. They have the fiduciary duties to render an account to the owners of the company on the company's business processes and procedures. This follows the assertion to keep businesses distinct from the shareholders (Etim, [2]). The accounting and reporting is usually by means of financial statements prepared annually. However, the contents of such financial statements will hugely be doubted if the external auditor did not verify it.

Corporate laws in virtually all economies of the world empower external auditors as professional experts to examine and form opinion on financial statements, including the power to ascertain if the financial statement was prepared in tandem with basic accounting tenets (Etim and Udoh, [1]). More so, the auditors are equally expected to exercise due care and expertise, be independent and be rational in their judgment. The responsibilities when effectively and efficiently discharged is suppose to enhance quality financial accounting and reporting.

The facts are, however, that for several decades past the directors and management of different reporting entities (companies) in all sectors of diverse economies have prepared and approved; and the auditors have as well reported on financial statements and accounts in a reasonable manner. Nonetheless, these financial statement certified to have shown healthy company's state of affairs by auditors often fail or show signs of distress shortly after the audit exercise (Etim, [2]). This brought the accounting profession under serious attacks and criticisms by the end users due to series of irregularities from the financial and audit failures. Increased cases of financial accounting and reporting irregularities and external audit failures cut across both developed and developing economies and in different sectors. What actually could have been responsible for these audit failures? Primarily, the objective of this study is to ascertain the reasons for audit failures and suggest ways to minimizing the failures. 

study:

The reasons hereunder served as motivation for this

$>$ It will shed light on main factors responsible for audit failures and in further researches;

$>$ It will help audit practitioners to have a knowledge of factors, so as to avoid them; and

$>$ It will help regulatory and statutory agencies in legal and standards formulation and implementation.

The rest of the study covers theoretical and empirical issues, methodology, comparison of cases and implications, conclusion and recommendations.

\section{THEORETICAL AND EMPIRICAL ISSUES}

This study anchor on two (2) theories - the Agency theory and the stakeholders' theory. In 1976, Jensen and Meckling propounded the Agency theory. The basic underlying principle of the theory is that, corporate organizations often serve as a link between individuals and the society. In this relationship, a contract exists between the owners (shareholders) of the entity as principal and those engaged to run the affairs (management) of the business as agents. The agents in this contract are required to report regularly to the principal on how resources entrusted to them are managed and controlled for their benefit, hence, the need for corporate reporting, a medium whereby the agents (management) communicate with the principal (owners). It is expected that the reporting should be true and fair and without bias or manipulation to enhance informed decision-making (Etim and Ihenyen, [3]). The auditors on their part are suppose to act on behalf of those that appoint them (shareholders/principal) in protecting their interest when carrying out their duties and responsibilities of auditing financial statements and reports. Thus, the theory emphasis accountability and transparency on the part of the key players and participants in the financial accounting and reporting value-chain.

Stakeholders Theory: This theory posit that management of firms owe a duty to the firms' important stakeholders. This principle collaborate with the normative approach to managing a firm, which says a firm is accountable to their different stakeholders. The directors and auditors of companies therefore owe these stakeholders the fiduciary responsibility of trust and high ethical level of morality in conducting the company's affairs.

Audit Failure: This happens when an auditor give an erroneous audit report on a financial report of a firm while the firm fail to exist thereafter. Literarily, this implies that the precarious situation that lead to that such situation were not conveyed to the shareholders, but eventually emerge leading to the misfortune of such firm. In other situation, audit failure could also arise due to when managements fail to present complete and accurate financial statements to the auditors who eventually fail to notice that due negligence or incompetence (Okoye, Okaro and Okafor, [4]). Hence, audit failure most times occur due to bad auditing process and incompetence of the auditors.
Though what constitute an effective auditing process has been topic of intense discussion among accounting scholars, yet, the following guidelines have been suggested: $>$ It depends on the outcome of the auditing report;

$>$ The employees must understand the workings of the organization as well as that of the industry in an objective manner. This corroborates with findings from past studies that asserts that audit quality significantly correlate with auditor's competency (Schwartz and Menon, [5]; Hogan and Jeter, [6]; Schauer, [7])

$>$ There must be a quality tripartite relationship among the internal auditor, the external auditor and the finance team in the organization (Bender, [8]).

Audit failures are "costly to stakeholders of a business, the auditors themselves, the accountancy profession and even the wider society as a whole, as reputations, rust and billions of dollars in investments are often washed down the drains" (Osaze, [9]). Audit failures are a global phenomenon and have been witnessed with great surprise almost in all countries of the world. Some of these spectacular cases in the one-half decade past include; the Enron-WorldCom, Polly peck International, Mirror Group News International, among others (Etim and Udoh, [1]). In Nigeria, although external auditors' carryout annual audit of banks, however, the Central Bank of Nigeria (CBN) "stress test in 2009 revealed that certain banks in Nigeria failed the test whereas only Union Bank survived (Etim and Udoh, [1]). Further examples of firms that has experienced audit failure include: Saga, African Petroleum Plc. Case, and many others particularly in the financial services sector.

Thus, review of more literatures would show additional reasons for audit failures. These factors as viewed from extant literature can be divided into two: those relating to auditor appointment (independence and integrity) factors and those that have to do with audit-firm level (reputation, specialization, qualification and proficiency, quality control) factors.

\section{A. Audit Failure Factors Relating to Auditor Appointment}

There are plethora of studies that has proffered reasons for audit failures following auditor appointment issues. Some of such studies pointed out the effectiveness of a company's audit system, the quality of the auditing work done, and material benefits from management of a firm (Sikka, [10]). The auditor appointment failure factors according to Yamani [11] mentioned factors such as: independence, tenure, and the relationship an auditor has with firm's board of directors. Using Kohlberg stage model, Ponemon and Gabhart [12], took an ethical approach to the subject. They opined that how an auditor behave ethically has a close relationship with how they act independently in a hypothetical situation when interests seems to conflict. They also found that independence judgements are significantly influenced by penalty related factors' and are less 'sensitive to affiliation factors. This implies that auditors with less ethical disposition are exposed to reporting flaws in the audit process as they may struggle to resist any potential incentive. Additionally, audit 
fees have equally been adduced as further reason for audit failures as they exhibit close relationship (Barkess and Simnett, [13]; Hillison and Kenedy; [14]; Palmrose, [15]).

Furthermore, the size of an audit team equally affect the quality of audit and auditing services. Thus the audit firm size has positive relationship with the quality of the services rendered by an auditor. Championing this assertion, Khashameh, [16] revealed that most auditor appointment are based on the familiarity that exist between management of a firm and the auditors. Hence, appointing an auditor base on such familiarity factors rather than demand for objectivity and higher level of audit quality, the audit may likely fail.

\section{B. Audit Failure Factors Relating to Audit Firm Level}

The audit market has been divided between the 'BigFour Firms' and others. The classification or division is based on certain features like: reputation, qualification and proficiency, industry specialization and quality control and the number of procedures involved in an auditing process (Dopuch and Simumic [17]). On large audit firms, De Angelo [18] submit that they always maintain their integrity as they are hardly lured with incentive in order not to compromise their standards. Hence, Moore and Scott [19], submit that the size of a firm correlate positively with the quality of auditing services rendered.

Altogether, reputation of an audit firm is very important in auditing services. Since it takes time to build reputation across all individuals in an organization, when achieved, commitment and maintenance is expected. This is mostly important as investors and financial regulators make use of financial information seen, reviewed and approved by auditors in making important decisions. Therefore, since these individuals do not stay within the organization but require this information, auditor reputation serves as an important proxy for the quality and accuracy of client financial statements (De Angelo, [18]). It does imply that when financial irregularities are found after an audit exercise, the audit has failed and reputation impaired.

On industry specialization, qualification and proficiency as a firm level factor for audit quality or audit failure, it has been shown that the knowledge of an auditor in a given industry is crucial in rendering an effective auditing services as it would help them in identifying fraudulent practices observed during auditing processes (Maletta and Wright, [20]; Carcello and Nagy, [21]). Specialization of an auditor equally determines his/her skills, qualification and proficiency. How knowledgeable an auditor is on the job; technical capability, the working experience and the certification process and training all have a bearing in the performance of audit procedures and program evaluation which in turn affect the audit quality or otherwise.

\section{METHODOLOGY}

Given the nature of the study and the objectives it seeks to achieve, ex-post facto research method is adopted involving comparative analysis of two (2) lead cases of external audit failures - one (1) Nigerian case representing developing economies and one (1) American case representing developed economies. The Nigerian is case is CADBURY Plc offer referred to Nigerian ENRON and the ENRON CASE proper. The choice of this comparative analysis is because auditing is a universal language that adapt common methods, procedures and generally accepted auditing standards with the same framework with the same raw materials - entities financial statements and adopted accounting policies and framework.

More so, the case study approach was used as the study deals with practical issues that exist in different firms and equally give the research the chance to incorporate other approach when necessary (Yin, [22]).

\section{ANALYSIS AND DISCUSSION OF RESULTS}

This section presents two specular financial reporting and external audit failure cases selected purposively based on their uniqueness to the business world and the accountancy profession in an abridge form followed by identification of key audit failure factors or drivers.

\section{- ENRON CASE - Arthur Andersen \& Co.}

The dimension of what transpired at ENRON Corporation follows the enquiry that was set up by management of ENRON shortly after two set of investigation; the Securities and Exchange Commission (SEC) investigation (The Powers' Report) and the extensive enquires of the Bankruptcy examiners (Batson, a, b, c $[23,24,25,26])$. The investigations centered on Enron's “off balance sheet operations, transactions between the firm its unconsolidated Special Purpose Entities (SPEs), and the demand of SPEs to protect the firms two years profitability report shortly after their collapse. The bankruptcy examiner's report showed how management of the firm influenced several financial reports. Details of this report is shown in Table 1.

It has been argued whether the misfortune Enron would had been avoided prior to their collapse. Studies such as Etim [2] is of the view that the misfortune would had been avoided if the external auditors were more effective, as this would had helped them to identify excess remuneration and other fraudulent schemes (Etim, :67 [2]). Elsewhere, Arthur Andersen \& Co's contend that certain individual of management status in the firm had interest in some financial report of the firm regardless of the policy that deals between Enron and those SPEs need to be approved. 
Summarily, the issues in the corporate accounting and auditing issues of Enron's failure are as follows:

- Arthur Andersen \& Co. assumed the position of an auditor and financial consultant to Enron;

- Inability of management of Enron to disclose their business dealings with SPEs;

- Inability of management of Enron to take note of the firms revenue which cumulated into increased net income for the firm;

- Re-statement or using unreliable information to overstate the firms asset and business dealings;

- Inability of management of Enron to account for the firms stock that was issued to and held by SPEs; and

- Inability of management of Enron to disclose their business transactions with other firm.

In spite of the above accounting irregularities, the external auditor still went on over the years to give wrong reports on the firm's financial standings. This compromises quality audit. It can be inferred from the above that:

- The external auditors were not entirely independent in discharging their duties;

- They exhibited lack of technical competence;

- Involvement on activities and duties that impair audit functions;

- Long tenure relationship between management and external auditors - familiarity threats;

- Alter disregard to accounting and auditing standards; all of these impair audit function and affects quality of audit, thus trigger for audit failures.

\section{* CADBURY NIG. PLC. CASE - Akintola Williams Deloitte (AWD)}

Akintola Williams Deloitte (AWD) is among the four big accounting firms in Nigeria with about 40 partners auditing the accounts of many big companies.

In 2006, it is stated that AWD was implicated in accounts falsification involving Cadbury Nigeria Plc, which was perpetrated by AWD in collaboration with the managing Director/CEO and the Finance Director of the firm (Etim, [2]). Summarily, the Administrative Proceedings Committee (APC) of the Nigerian Security and Exchange Commission (the SEC) confirmed that N13.255 billion (\$106 million) was overstatement for the years 2002 to September 2006 which AWD had audited the published accounts for those years (SEC APC, [27]).

To summarize the SEC report on the case, the following are the issues raised:

- Failure of the firm to disclose N13.255 billion loss of the company for the years 2002 to September 30, 2006;

- Failure of the firm to confirm N7.7 billion allegedly credited to company's account in 2005 ;

- Failure of the firm to react appropriately when the management fail to explain the queries raised by the firm;
- Lending its name to a false profit forecast in a rights issue by the company during the period;

- Inability of the firm to show professional diligence in an enquiry involving a disclaimer by a customer of the company;

- Inability to show financial insight regardless of the internal control mechanisms that were put in place; and

- Holistic lack of professional insight and diligence by the firm and its partners regardless of how knowledgeable they are on the job (SEC Report, [28]).

\section{$>$ Reflections and Implications}

The analyses of the 2 audit failure cases draw from a well-developed market economy and a developing market economy. These cases were purportedly selected with a view to balancing external audit procedures in both developed and developing economics and on the premise that external auditing is a universal process that 'fit-in-toall' financial statement audit irrespective of the economy of company is situated.

In respect of the evidences presented above, the external auditors failed to discharge their duties in a professional manner. The implication being that they lack independence in rendering services that require ethical behaviour. Professional accountants are not supposed to be reckless in discharging their duties nor attest to information that is false or misleading. The causes of external audit failures in the 2 corporate cases analyzed can be summed up as follows:

- Connivance between external auditors and clients as a result of unholy nexus;

- Fee dependence and excessive desire for economic gain, hence fear of losing a valued client;

- Long firm-client relationship that spanned over 5 years or more;

- External auditors also serving as internal auditors to client;

- Blatant disregard to accounting and auditing standards by auditors;

- Lack of valuable knowledge and technical competence in acceptance of some engagements they lack requisite capability;

- Rendition of multiple services in the form of management advisory services (MAS), among others.

- High level of unprofessional attitudes.

The above listed issues/factors are directly and indirectly identified in the two cases analyzed in this study, and are as well common in such other audit failures like $\mathrm{HIH}$ Insurance (Australia) (2001)-Arthur Anderson; Yinguangxia (YGX) (China) (2001)-Zhongtianqin (ZTQ) CPA Firm; Adelphia (USA) (2002) -Deloitte \& Touche; Worldcom Scandal (USA) (2002) Arthur Andersen; Parmalat (Italy) (2003)-Grant Thornton International (GT) CPA firm; and many others. 


\section{CONCLUSION AND RECOMMENDATIONS}

In recent years, corporate financial accounting and reporting failures and scandals all over the world have been widely reported resulting to negative view and consistent infamous press toward the accountancy profession. With international corporate reporting maneuver by unscrupulous management of companies through creative accounting and window dressing practices, external audits are required to guide against, misjudgment, and other unprofessional accounting practices shown by management of different firms. Nevertheless, the success of these safeguards hang on the auditors' professional competence, integrity, objectivity, due to care in the discharge of their duties to clients, carefulness and independence in the auditing process.

Having identified some of the drivers of audit failures in the analyzed cases and from other extant literature and the fact that the audit failures have tarnished the credibility and trust reposed on the accountancy profession as a public interest profession, the following recommendations are made:

- Regulatory Authorities saddled with regulations of financial reporting and audit of public companies are expected to improve oversight of public companies and sanction any person or group involve in maneuvering financial reports and violating financial accounting and reporting principles and guideline.

- Professional accountants should adhere to ethical codes of conduct in any engagement as findings shows auditors were morally dishonest as the findings here consistent with that of Bakess [13].

- The study supports periodic change of audit firms in every 4-5 years to reduce over familiarity of auditors with client's management and staff; findings were collaborated by studies (Iwok, [30]; Otusanya, [31]).

- Auditors should be prohibited from undertaking several other Management Advisory Services (MAS) except those directly relating to the specific audit duty on hand. The findings and recommendations are collaborated by the studies of Etim, [2] and [1].

- Accounting and auditing standards and guidelines should be regularly reviewed and updated in line with contemporary developments in the business world such electronic based transactions and auditing.

- Corporate governance structure should be strengthened especially in the area of audit committees and those appointed into its membership to include people with financial accounting and auditing knowledge.

- The professional bodies at the national levels and global levels should impose more stringent sanctions on members involved in unethical or antisocial practices to serve as a deterrent to others.

\section{$>$ Direction for Future Research}

It is suggested further empirical research be conducted on audit failures and educational curriculum structure in tertiary institutions. Also, audit failures and investors' behaviour in the capital markets.

\section{REFERENCES}

[1]. Etim, E. O. and Udoh, J. E. (2015). The Impairment of Audit Functions. An Assessment of some Causes, Tropical Focus, International Journal Services on Tropical Issues, vol.15(3) pp.116-124.

[2]. E. Etim. O. (2013a). Exchanging the Quality of External Audit. African Journal of Contemporary Issues, vol.13(02) pp.59-89.

[3]. E. Etim, O. and Ihenyen, C. J. (2013). Corporate Reporting Maneuver Effects and Implications: A Discourse. Tropical Focus, International Journal Series on Tropical Issues, vol.14(1) pp.155-166.

[4]. E. Okoye, I., Okaro, S. C. and Okafor, G. O. (2015). Fighting the Scourge of Audit Failures in Nigeria. Journal of Academic Research in Business and Social Sciences, vol.5(5) pp.105-114.

[5]. K. Schwartz, B. and Menon, K. (1985). Auditor Switches by Failing Firms. The Accounting Review, vol.60(April) pp.248-261.

[6]. C. Hogan, E. and Jeter, D. C. (1999). Industry Specialization by Auditors. Auditing: A Journal of Practice and theory, vol.18 (Spring) pp. 1-17.

[7]. D. Schauer, (2000). The Question of Audit and Quality. Journal of Accountancy and Auditing, vol.2(2) pp.33-37.

[8]. R. Bender, (2006). What is an Effective Audit and how can you tell? Audit Committee chair Forum: 113).

[9]. E. Osaze, (2011). The Specificities of Value Melt down in the Nigerian Stock Exchange 2008-2010. Professional Chair Lecture, University of Benin, Nigeria: pp.1-19.

[10]. P. Sikka, (2009). Financial Crisis and the Silence on the Auditors. Accounting, Organizations and Society, vol. 24(2) pp.135-155.

[11]. A. Yamani, (1991). The Factors that Affect on External Auditor Independency from Point of Views the Analysts and Borrowers in the Saudi Arabia. General Management Journal, Al-Riyadh, vol.71 pp.183-229.

[12]. L. Ponemon, A. and Gabhart, D. R. (1990). Auditor Independence Judgements: A CognitiveDevelopmental Model and Experimental Evidence. Contemporary Accounting Research, vol.7(1) pp.227251.

[13]. L. Bakess, and Simnette, R. (1992). An Empirical Investigation of the Relationship between Audit Fees and the Provision of other Services by Incumbent Auditor: Australian Evidence. Journal of Accounting and Auditing, vol.02(19)pp 113-121

[14]. W. Hillson, and Kennedy, M. (1988). The Economics of Non-audit Services. Accounting Horizons, vol.2(3) pp.117-123.

[15].Z. Palmrose, (1986). An Analysis of Auditor Litigation and Audit Service Quality. The Accounting Review, vol.63(January) pp.55-73.

[16]. A. Khasharmeh, (2002). The Factors that Affect on External Auditor in the Jordanian Public Companies. Field Survey, Faculty of Economics and Administration Sciences Journal, vol.4(2) pp.34-51. 
[17]. N. Dopuch, and Simunic, D. (1982). Competition in Auditing: An Assessment. Paper Presented at Symposium on Auditing Research iv, University of Illinois at Urbana. Champaign, 53pp.

[18]. L. De Angelo, (1981). Auditor Size and Audit Quality. Journal of Accounting and Economics, vol. 3(3) pp.189-199.

[19]. M. Maletta, and Wright, A. (1996). Audit Evidence Planning: An Examination of Industry Error Characteristics. Auditing: A Journal of Practice and Theory, vol.15(Spring) pp.71-86.

[20]. J. Carcello, and Nagy, A. (2004). Client Size, Auditor Specialization and Fraudulent Financial Reporting. Managerial Auditing Journal, vol.5 pp.651-668.

[21]. R. Yin, (2003). Case Study Research: Design and Methods, $3^{\text {rd }}$ ed. California: SAGE, 482pp.

[22]. N. Batson, (2002). First Interim Report of Neal Batson Court Appointed Examiners. Available at: http://www.enron.com/por/pdf/ReportIoff.Examiner.p df.

[23]. N. Batson, (2003a). Second Interim Report of Neal Batson Court Appointed Examiners. Available @: http://www.enron.com/corp/pro/pdfs/Examiner.2/Exa minersReport2.pdf.

[24]. N. Batson, (2003b). Third Interim Report of Neal Batson Court Appointed Examiners. Available at: http://www.enron.com/corp/por/pdfs/examiners 3/examinersreport3.pdf.

[25]. N. Batson, (2003c). Final Report of the Court Appointed Bankruptcy Examiners. Available at: http://www.enron.com/corp/por/pdfs/examinersfinal/h tml.

[26]. Securities and Exchange Commission (SEC) (2003) Administrative Proceedings Commission, Accounting Releases, 120pp.

[27]. SEC. Report (2008).

[28]. E. Iwok, R. (1998). Accountability, Transparency and Stewardship. A Paper Delivered at the Continuing Professional Development Programme - ANAN, Umuahia, August, 1998, 32pp.

[29]. J. Otusanya, O. (2010). The Role of Auditors in the Nigeria Banking Crisis. Accountancy, Business and the Public Interest, vol.9(01) pp.159-204. 